
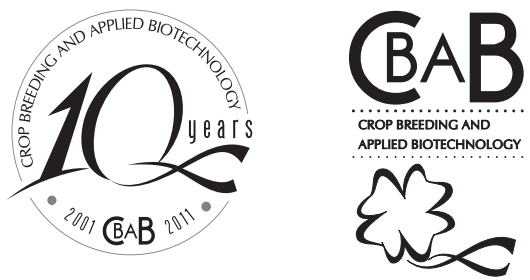

\title{
Development and application of microsatellites in plant breeding
}

\author{
Maria Celeste Gonçalves-Vidigal $^{1 *}$ and Luciana Benchimol Rubiano ${ }^{2}$
}

Received 31 March 2011

Accepted 20 May 2011

\begin{abstract}
Molecular markers are powerful tools for analyzing genome diversity within a species, and to evaluate genetic relationships between individuals and populations. Among them, microsatellites (SSRs) are one of the most important polymorphic markers that can be used effectively to distinguish germplasm accessions. These markers present high informative content due to their codominant inheritance, multiallelism, mendelian pattern and good genome coverage. The enrichment methodology for microsatellite development has a superior efficiency in plants, especially when performed using biotin-labeled microsatellite oligoprobes and streptavidin-coated magnetic beads. The development of EST-SSR markers has become a fast and relatively inexpensive way but it is limited to species for which this type of database exists. Given the high polymorphism level of microsatellites when compared to other markers, SSRs have been used to study population structure, for genetic diversity analysis, genetic mapping and marker assisted selection.
\end{abstract}

Key words: common bean, genetic diversity, microsatellites, plant breeding.

\section{INTRODUCTION}

Hybridization method is very commonly used in crop breeding in order to obtain segregant populations portraying interesting agronomical traits and broad genetic variability. This method combines available genes from two or more different genitors in a unique individual (Allard 1999).

The choice of genitors is very important in this process because it assures the obtaining of promising segregant populations. This procedures is based on genetic dissimilarity of the subject under study. In plants, genetic diversity may be inferred through quantitative (phenotypic ou genotypic traits) and predictive charecteristics. The quantitative genetic diversity is usually calculated from a set of genotypic or phenotypic characters, throught the use multivariate statistics (Das and Gupta
1984). Predictive methods are those based on morphological, physiological or molecular differences, quantifying then in some similarity/dissimilarity measurement, which may express the degree of parental genetic diversity (Cruz et al. 2004).

However, due to high environmental influence on morphoagronomic characteristics, many researchers have chosen predictive techniques for estimating genetic diversity as they reduce the necessity of hybridization among progenitors (Ceolin et al. 2007), diminishing labor and expenses with a great number of crosses and field experiments.

Molecular markers are powerful tools for analyzing genome diversity within a species, and to evaluate genetic relationships between individuals and populations. They have been used for mapping of genomic regions containing

${ }^{1}$ Universidade Estadual de Maringá, Departamento de Agronomia, Av. Colombo, 5790, 87.020-570, Maringá, PR, Brazil. * E-mail: mcgvidigal@uem.br
${ }^{2}$ Instituto Agronômico (IAC), Centro de Análises e Pesquisa Tecnológica do Agronegócio dos Grãos e Fibras, C. P. 28, 13.001-970, Campinas, SP, Brazil 
genes of agricultural interest (Charcosset and Moreau 2004). In recent years, genetic divergence studies in different crops have often used microsatellite as the main tool for genetic diversity analysis.

Microsatellites or SSRs (Simple Sequence Repeats, Tautz 1989) are one of the most indicated techniques to study polymorphism between DNA sequences. These molecular markers are based on PCR reaction that detects loci variations of repetitive sequences. They present high levels of polymorphism, codominant inheritance, multiallelism, mendelian pattern and good genome coverage. Microsatellites require low amount of DNA, can be easily automated for high throughput screening, may be exchanged between laboratories, and are highly transferable between populations (Gupta et al. 2003).

SSRs occur frequently within or near genes in plants (Morgante et al. 2002). Comparing coding and non-coding regions in different plant species, it was observed that tri and tetra-nucleotide microsatellite motives are more common within introns, whereas other types of motives are found within exons (Tóth et al. 2000). Morgante et al. (2002) reported a selective pressure acting over untranslated 3' and 5' regions (UTR) of genes, favoring a higher pressure of SSRs in these regions than in the rest of the genome. The 5'-UTR presents a higher CT and CTT number of repetitions, while the 3'UTR showed to be rich in $\mathrm{AG}$ and $\mathrm{AAG}$. Regions of DNA involved in gene regulation are expected to exhibit sequence conservation between related species over evolutionary time due to functional constraints. Microsatellite transferability amongst related species is allowed by the homologous nature of the DNA sequence in microsatellite flanking regions (Varshney et al. 2005).

\section{Microsatellite enriched libraries development}

The development of microsatellite markers involves several distinct steps from obtaining the library to developing a working set of primers that can amplify polymorphic microsatellite loci.

Traditional methods for developing microsatellites have a low efficiency and can be time-consuming, especially in the selection stage and clone screening (Zane et al. 2002). Ostrander et al. (1992) proposed the enrichment methodology for microsatellites achieving enrichment 50 times superior to genomic libraries. The selective hybridization protocols are very commonly used in microsatellite enrichment (Kijas et al. 1994, Billotte et al. 1999).

Crop Breeding and Applied Biotechnology S1: 66-72, 2011

\section{Example 1}

\subsection{Construction of an enriched microsatellite library for common beans}

An enriched library was constructed according to Billotte et al. (1999) for IAC-UNA according to Benchimol et al. (2007). The first step was to quantify the genomic DNA (200 $\mathrm{ng} \mathrm{mL}$ ) extracted using CTAB method (Hoisington et al. 1994) on agarose gel. The selection of microsatellite sequences was performed using biotinlabeled microsatellite oligoprobe and streptavidin-coated magnetic beads following a hybridization-based capture methodology adapted from Kijas et al. (1994).

Plasmids form positive clones containing microsatellites were extracted by plasmid DNA minipreparation. All clones were sequenced in both directions. Reads were processed by the Phred version 0.000925.c base calling program (Ewing et al. 1998) and vector sequences, poly-A tail, and adapters were trimmed after cross-match analysis. Only perfect and/or imperfect sequences containing to five or more repeated units were considered. Complementary primers to single sequences, flanking the microsatellites, were designed. Stringency criteria adopted was based on GC content between 40 and $60 \%$, melting temperature between 46 and $60^{\circ} \mathrm{C}$, a salt concentration of $50 \mathrm{mM}$, and a product length between 150 and $300 \mathrm{pb}$.

\subsection{Genic microsatellites from EST database}

The major constraint of using SSR markers from genomic libraries is the high development cost and effort required to obtain working primers for a given study species. With the establishment of expressed sequence tag (EST) sequence projects for many plant species, a great amount of information and DNA sequences were generated and deposited in online databases. The development of EST-based SSR markers through data mining has become a fast, efficient, and relatively inexpensive compared with the development of genomic SSRs (Gupta et al. 2003). Genbank (www.ncbi.nlm.nih.gov/ genbank/), for instance, gathers a great amount of EST sequences, gene and cDNA clones. The TIGR Institute (The Institute for Genomic Research - <http://www.tigr.org/ tdb/e2k1/plant.repeats/>) possesses an EST database for many cultivated plant species of economic importance and therefore, it is hard to find sequences of wild species.

Many programs that have been developed for recognition of SSR patterns in the sequence files, such as 
the 'Tandem Repeats Finder' - TRF (Benson 1999), the 'Simple Sequence Repeat Identification Tool' - SSRIT (Temnykh et al. 2001, <http://www.gramene.org/db/ searches/ssrtool>), and program MISA (Micro Satellite) identification tool (<http://pgrc.ipk-gatersleben.de/misa/>). A major disadvantage of EST-derived microsatellites is the sequence redundancy that yields multiple set of markers at the same locus. Therefore it is very important to verify the existence of redundancy among sequences and BLASTN tool (NCBI; <http://blast.ncbi.nlm.nih.gov/ Blast.cgi>) could be used for that purpose.

\section{Application of microsatellites in plant breeding}

Microsatellites have been used for plant genetic analysis such as to measure the effects of natural selection (Rodrigues and Santos 2006), to unveil the genetic diversity (Vieira et al. 2009, Guan et al. 2010), to measure population structure (Ribeiro et al. 2010, Albertini et al. 2011), to integrate the genetic, physical and sequence-based physical maps (McClean et al. 2010, Garcia et al. 2011) and for marker assisted selection (Benchimol et al. 2005, Chen et al. 2011).

\section{Using microsatellite in genetic diversity and population structure in common bean}

Molecular marker analysis has contributed for the understanding of common bean genetic structure diversity and phylogenetic analysis (Asfaw et al. 2009). For molecular markers, such as RAPD, SSR, and RFLP, there were major findings such as plant population continuous variation and high level of dissimilarity within population and among germplasm collections. Microsatellite markers are involved not only in genetic diversity studies, population genetics and evolutionary studies, but are also being used in fundamental research like genome analysis, gene mapping and marker-assisted selection (Kalia et al. 2011).

Given the high polymorphism level of microsatellites when compared to other markers, many worldwide researchers have preferred using these markers on the study of common bean population structure, genetic divergence and genetic mapping (Díaz and Blair 2006, Hanai et al. 2007, Blair et al. 2009, Campos et al. 2011).

\section{Example 2}

\section{Genetic divergence and population structure in common bean using microsatellite}

The assessment of genetic diversity and population structure of 122 accessions of common bean from Brazil and Africa was performed using microsatellites, genetic distance estimates and probabilistic models to analyze population structure.

Sixteen microsatellite markers from all the 11 linkage groups of $P$. vulgaris L. gene map were selected for analyses based on their dispersed map location. Markers originated from genic and genomic sequences were chosen in equal proportions (Yu et al. 2000, Gaitán-Solís et al. 2002, Blair et al. 2003, Grisi et al. 2007). Microsatellite analysis was conducted as described by Kwak and Gepts (2009), including an economic method of microsatellite fluorescent labeling of fragments amplified by PCR (Schuelke 2000).

Microsatellite methods employing fluorescent labeling and automated band calling with precise softwarebased allele detection are considered the most accurate way of genotyping (McCouch et al. 1997, Blair et al. 2002). Additionally, this sort of labeling organizes markers into distinct dye color panels allowing multiplexing during band separation, with advantages of high throughput genotyping and simultaneous analysis of multiple loci (Coburn et al. 2002, Oblessuc et al. 2009).

The methodology of multiplexing can also be carried out in PCR amplification step with mixtures of the appropriate primers (Hayden et al. 2008). Current technology allows capillary-based separation of microsatellite bands with four different color panels, one for each individual marker, which can be evaluated through a single capillary with a separate size standard, allowing precise band size estimates (Coburn et al. 2002).

The amplified fragments were multiplexed depending on their size variation and analyzed in an ABI 3730 (Applied Biosystems). Genotypes of markers were determined using the GeneMarker program (version1.51, SoftGenetics). The genetic relationship among entire accessions was analyzed by principal coordinate analysis performed using the GenAlex 6 Program (Peakall and Smouse 2006).

The genetic distance among 122 Andean and Mesoamerican accessions was calculated using the C.S. Chord distance (Cavalli-Sforza and Edwards 1967). The C.S. Chord distance does not require any mutation model for microsatellite evolution and is free from bottleneck effect (Takezaki and Nei 1996). Based on this genetic distance, an unrooted neighbor-joining (NJ) tree was constructed in PowerMarker (Liu and Muse 2005). Distinct clusters were apparent with the SSR markers unambiguously assigning accessions to the Andean and Mesoamerican gene pools with the $2 \mathrm{D}$ plot of the PCoA based on pairwise genetic distances. 
The obtained results demonstrated that Andean gene pool accessions from Brazil and Africa were clustered together showing a great genetic similarity. Likewise, the Mesoamerican accessions from both countries formed a second group. These results indicate the possibility of introgression between countries. Some African accessions with low genetic similarity could be use in breeding programs to broaden the genetic base of Brazilian cultivars.

\section{Example 3}

\section{Potential application of SSR markers for mapping and tagging disease resistance genes common bean}

Anthracnose (ANT) caused by Colletotrichum lindemuthianum (Sacc.) Scrib and angular leaf spot (ALS) caused by Pseudocercospora griseola (Sacc.) Crous e U. Braun, are the most widespread, recurrent and devastating diseases of common bean in Latin America and Africa. Use of disease resistance genes is the most practical, costeffective and environmentally friendly strategy for the control of ANT and ALS. Resistance to various diseases in common bean is conferred mostly by single, dominant genes with race-specific resistance (R-genes). Resistance to $C$. lindemuthianum is conditioned by some 13 reported genes identified by the Co symbol (Kelly and Vallejo 2004). Six independent dominant genes identified by the $P h g$ symbol condition resistance to $P$. griseola (Caixeta et al. 2005).

Recent studies were conducted at the Laboratório de Biotecnologia do Núcleo de Pesquisa Aplicada a Agricultura (NUPAGRI) of the Universidade Estadual de Maringá (Paraná, Brazil) to study the co-segregation between ANT and ALS resistance genes that confer resistance to $C$. lindemuthianum and $P$. griseola, respectively. A total of 112 individual $F_{2}$ derived from a cross between resistant and susceptible parents were inoculated with races 73 of $C$. lindemuthianum and 63-39 of $P$. griseola. The analysis was performed using 22 SSR markers. Two contrasting DNA bulks (Michelmore et al. 1991) were constructed by pooling equal volumes of fluorometrically standardized DNA from four to six resistant and susceptible individuals, respectively, of the $\mathrm{F}_{2}$ population. Of these 22 SSR markers, the g2303 showed contrasting amplification patterns in parental materials and in resistant vs. susceptible bulks or individuals. Segregation analyses of the disease reaction from $\mathrm{F}_{2}$ plants were performed by the chi-square $\left(\chi^{2}\right)$ test, according to a Mendelian segregation hypothesis of $3 \mathrm{R}$ _(resistant) to $1 \mathrm{rr}$ (susceptible). Linkage analyses were performed using the computer software Mapmaker/exp 3.0 (Lincoln and Lander 1993). The results of molecular mapping revealed that the SSR marker g2303 was linked at $0.9 \mathrm{cM}$ from ANT resistance gene and $1.8 \mathrm{cM}$ from ALS resistance gene in coupling phase with both genes, and mapped at linkage group Pv04 in the common bean linkage map. The co-segregation between these genes revealed the possibility of monitoring those genes indirectly through the use of g2303 molecular marker. Similar results were obtained by Gonçalves-Vidigal et al. 2011). In this study, the findings might help plant breeding programs to reduce time and cost associated with pyramiding resistance genes to different pathogens.

\section{ACKNOWLEDGEMENTS}

We would like to thank to SBMP, CNPq, Capes, FAPESP for the financial support. MC Gonçalves-Vidigal is sponsored by grants from $\mathrm{CNPq}$. 


\title{
Desenvolvimento e aplicação dos microssatélites no melhoramento de plantas
}

\begin{abstract}
RESUMO - Marcadores moleculares são ferramentas auxiliares nas análises da diversidade genômica dentro de uma espécie e para avaliar os relacionamentos entre indivíduos e populações. Dentre eles, os microssatélites (SSRs) é uma das classes de marcadores mais importante que pode ser usada com eficiência para distinguir acessos provenientes de um banco de germoplasma. Estes marcadores apresentam elevado grau de informação devido a sua herança co-dominante, multialelismo, padrão mendeliano e boa cobertura do genoma. A metodologia de enriquecimento para o desenvolvimento de microssatélites apresenta uma eficiência superior em plantas, especialmente quando se utiliza sondas marcadas com biotina e esferas magnéticas revestidas com estreptavidina. O desenvolvimento de EST-SSRs tem se tornado uma forma rápida para obtenção de marcadores moleculares, porém limitada a espécies para as quais existam bancos de sequências. Dado o elevado nível de polimorfismo dos microssatélites quando comparados com outros marcadores, estes têm sido utilizados em estudos da estrutura genética de populações, em análises de diversidade genética, em mapeamento genético e em seleção assistida por marcadores.
\end{abstract}

Palavras-chave: diversidade genética, feijoeiro comum, melhoramento de plantas, microssatélites.

\section{REFERENCES}

Albertini E, Torricelli R, Bitocchi E, Raggi L, Marconi G, Pollastri L, Minco G, Battistini A, Papa R and Veronesi F (2011) Structure of genetic diversity in Olea europaea L. cultivars from central Italy. Molecular Breeding 27: 533-547.

Allard RW (1999) Principles of plant breeding. $2^{\text {nd }}$ ed., J. Wiley \& Sons, New York, 247p.

Asfaw A, Blair M and Almekinders C (2009) Genetic diversity and population structure of common bean (Phaseolus vulgaris L.) landraces from the East African highlands. Theoretical and Applied Genetics 120: 1-12.

Benchimol LL, Souza Jr CL and Souza AP (2005) Microsatelliteassisted backcross selection in maize. Genetics and Molecular Biology 28: 789-797.

Benchimol LL, Campos T, Carbonell SAM, Colombo CA, Chioratto AF, Formighieri EF, Gouvêa LRL and Souza AP (2007) Structure of genetic diversity among common bean (Phaseolus vulgaris L.) varieties of Mesoamerican and Andean origins using new developed microsatellite markers. Genetic Resources and Crop Evolution 54: 1747-1762.

Benson G (1999) Tandem repeats finder: a program to analyze DNA sequences. Nucleic Acids Research 27: 573-580.

Billotte N, Lagoda PJL, Risterucci AM and Baurens C (1999) Microsatellite-enriched libraries: applied methodology for the development of SSR markers in tropical crops. Fruits 54: 277288 .

Blair MW, Hedetale V and McCouch SR (2002) Fluorescent-labeled microsatellite panels useful for detecting allelic diversity in cultivated rice (Oryza sativa L.). Theoretical and Applied Genetics 105: 449-457.
Blair MW, Pedraza F, Buendia HF, Gaitán-Solís E, Beebe SE, Gepts P and Tohme J (2003) Development of a genome-wide anchored microsatellite map for common bean (Phaseolus vulgaris L.). Theoretical and Applied Genetics 107: 1362-1374.

Blair MW, Díaz LM, Buendía HF and Duque MC (2009) Genetic diversity, seed size associations and population structure of a core collection of common beans (Phaseolus vulgaris L.). Theoretical and Applied Genetics 119: 955-972.

Caixeta ET, Borém A and Kelly JD (2005) Development of microsatellite markers based on BAC common bean clones. Crop Breeding and Applied Biotechnology 5: 125-133.

Campos T, Oblessuc PR, Sforça DA, Cardoso JMK, Baroni RM, Sousa ACB, Carbonell SAM, Chioratto AF, Garcia AAF, Rubiano LB and Souza AP (2011) Inheritance of growth habit detected by genetic linkage analysis using microsatellites in the common bean (Phaseolus vulgaris L.). Molecular Breeding 27: 549560 .

Cavalli-Sforza LL and Edwards AWF (1967) Phylogenetic analysis: models and estimation procedures. American Journal of Human Genetics 19: 233-257.

Ceolin ACG, Gonçalves-Vidigal MC, Vidigal Filho PS, Kvitschal MV, Gonela A and Scapim CA (2007) Genetic divergence of the common bean (Phaseolus vulgaris L.) group Carioca using morpho-agronomic traits by multivariate analysis. Hereditas 144: 1-9.

Charcosset A and Moreau L (2004) Use of molecular markers for the development of new cultivars and the evaluation of genetic diversity. Euphytica 137: 81-94.

Chen L, Zhao Z, Liu X, Liu L, Jiang L, Liu S, Zhang W, Wang Y, Liu Y and Wan J (2011) Marker-assisted breeding of a photoperiod -sensitive male sterile japonica rice with high cross-compatibility with indica rice. Molecular Breeding 27: 247-258. 
Coburn JR, Temnykh SV, Paul EM and McCouch SR (2002) Design and application of microsatellite marker panels for semi automated genotyping of rice (Oryza sativa L.). Crop Science 42: 2092-2099.

Cruz CD, Regazzi AJ and Carneiro PCS (2004) Modelos biométricos aplicados ao melhoramento genético. Editora UFV, Viçosa, 480p.

Das PK and Gupta TD (1984) Multivariate analysis in black grain [Vigna mungo (L.) Herpper]. Indian Journal of Genetics and Plant Breeding 44: 243-247.

Díaz LM and Blair MW (2006) Race structure within the Mesoamerican gene pool of common bean (Phaseolus vulgaris L.) as determined by microsatellite markers. Theoretical and Applied Genetics 114: 143-154.

Ewing B, Hillier L, Wendl MC and Green P (1998) Base-calling of automated sequencer traces using Phred. I. Accurancy assessment. Genome Research 8: 175-185.

Gaitán-Solís E, Duque MC, Edwards KJ and Tohme J (2002) Microsatellite repeats in bean (Phaseolus vulgaris): isolation, characterization and cross-species amplication in Phaseolus spp. Crop Science 42: 2128-2136.

Garcia A, Calvo ES, Kiihl RAS and Souto ER (2011) Evidence of a susceptible allele inverting the dominance of rust resistance in soybean. Crop Science 51: 32-40.

Gonçalves-Vidigal MC, Cruz AS, Garcia A, Kami J, Vidigal Filho PS, Sousa LL, McClean P, Gepts P and Pastor-Corrales MA (2011) Linkage mapping of the Phg-1 and Co- $1^{4}$ genes for resistance to angular leaf spot and anthracnose in the common bean cultivar AND 277. Theoretical and Applied Genetics 122: 893-903.

Gupta PK, Rustgi S, Sharma S, Singh R, Kumar N and Balyan HS (2003) Transferable EST-SSR markers for the study of polymorphism and genetic diversity in bread wheat. Molecular Genetics and Genomics 270: 315-323.

Grisi MCM, Blair MW, Gepts P, Brondani C, Pereira PAA and Brondani RPV (2007) Genetic mapping of a new set of microsatellite markers in a reference common bean (Phaseolus vulgaris) population BAT93 x Jalo EEP558. Genetic and Molecular Resource 6: 691-706.

Guan R, Chang R, Li Y, Wang L, Liu Z and Qiu L (2010) Genetic diversity comparison between Chinese and Japanese soybeans (Glycine $\max$ (L.) Merr.) revealed by nuclear SSRs. Genetic Resources and Crop Evolution 57: 229-242.

Hanai LR, Campos T, Camargo LEA, Benchimol LL, Souza AP, Melotto M, Carbonell SAM, Chioratto AF, Consoli L, Formighieri EF, Siqueira MVBM, Tsai SM and Vieira MLC (2007) Development, characterization, and comparative analysis of polymorphism at common bean SSR loci isolated from genic and genomic sources. Genome 50: 266-277.
Hayden MJ, Nguyen TM, Waterman A, McMichael GL and Chalmers KJ (2008) Application of multiplex-ready PCR for fluorescencebased SSR genotyping in barley and wheat. Molecular Breeding 21: 271-281.

Hoisington D, Khairallah M and Gonzalez-de-Leon D (1994) Laboratory protocols: CIMMYT applied molecular genetics laboratory. $2^{\text {nd }}$ ed., CIMMYT, Mexico, 50p.

Kalia RK, Rai MK, Kalia S, Singh R and Dhawan AK (2011) Microsatellite markers: an overview of the recent progress in plants. Euphytica 177: 309-334

Kelly JD and Vallejo V (2004) A comprehensive review of the major genes conditioning resistance to anthracnose in common bean. HortScience 39: 1196-1207.

Kijas JM, Fowler JC and Garbett CA (1994) Enrichment of microsatellites from the citrus genome using Bi-Otinylated oligonucleotide sequences bound to streptavid in-coated magnetic particles. Biotechniques 16: 657-662.

Kwak M and Gepts P (2009) Structure of genetic diversity in the two major gene pools of common bean (Phaseolus vulgaris L., Fabaceae). Theoretical and Applied Genetics 118: 979-992.

Lincoln SE and Lander SL (1993) Mapmaker/exp 3.0 and Mapmaker/QTL 1.1. Constructing genetic maps with Mapmaker Exp 3.0. Whitehead Institute for Biometrical Research, Cambridge, 230p.

Liu K and Muse SV (2005) PowerMarker: integrated analysis environment for genetic marker data. Bioinformatics 21: 2128-2129.

McClean P, Mamidi S, McConnell M, Chikara S and Lee R (2010) Synteny mapping between common bean and soybean reveals extensive blocks of shared loci. BMC Genomics 11: 184.

McCouch SR, Chen X, Panaud O, Temnykh S, Xu Y, Cho YG, Huang N, Ishii T and Blair M (1997) Microsatellite marker development, mapping and applications in rice genetics and breeding. Plant Molecular Biology 35: 89-99.

Michelmore RW, Paran J and Kesseli RV (1991) Identification of markers linked to disease-resistance genes by bulked segregant analysis: a rapid method to detect markers in specific genomic regions by using segregation populations. Proceedings of the National Academy of Science 88: 9828-9832.

Morgante M, Hanafey M and Powell W (2002) Microsatellites are preferentially associated with nonrepetitive DNA in plant genomes. Nature Genetics 30: 194-200.

Oblessuc PR, Campos T, Cardoso JMK, Sforça DA and Baroni RM (2009) Adaptation of fluorescent technique for genotyping with new microsatellite markers in common bean. Pesquisa Agropecuária Brasileira 44: 638-644.

Ostrander EA, Jong PM, Rine J and Duyk G (1992) Construction of small insert genomic DNA libraries highly enriched for microsatellite repeat sequences. Proceedings of the National Academy of Sciences 89: 3419-3423. 
Peakall R and Smouse PE (2006) GenAlex 6: genetic analysis in excel: population genetic software for teaching and research. Molecular Ecology Notes 6: 288-295.

Ribeiro FE, Baudouin L, Lebrun P, Chaves LJ, Brondani C, Zucchi MI and Vencovsky R (2010) Population structures of Brazilian tall coconut (Cocos nucifera L.) by microsatellite markers. Genetics and Molecular Biology 33: 696-702.

Rodrigues TB and Santos JB (2006) Effect of natural selection on common bean (Phaseolus vulgaris) microsatellite alleles. Genetics and Molecular Biology 29: 345-352.

Schuelke M (2000) An economic method for the fluorescent labeling of PCR fragments. Nature Biotechnology 18: 233-234.

Silva GF, Santos JB and Ramalho MAP (2003) Identification of SSR and RAPD markers linked to a resistance allele for angular leaf spot in the common bean (Phaseolus vulgaris) line ESAL 550. Genetics and Molecular Biology 26: 459-463.

Takezaki N and Nei M (1996) Genetic distances and reconstruction of phylogenetic trees from microsatellite DNA. Genetics 144: 389-399.

Tautz D (1989) Hipervariability of simple sequences of a general source for polymorphic DNA markers. Nucleic Acids Research 17: 6463-6471.

Temnykh S, Declerck G, Lukashova A, Lipovich L, Cartinhour S and McCouch S (2001) Computational and experimental analysis of microsatellites in rice (Oryza sativa L.): frequency, length variation, transposon associations, and genetic marker potential. Genome Research 11: 1441-1452.
Thomson MJ, Septiningsih EM, Suwardjo F, Santoso TJ, Silitonga TS and McCouch SR (2007) Genetic diversity analysis of traditional and improved Indonesian rice (Oryza sativa L.) germplasm using microsatellite markers. Theoretical and Applied Genetics 114: 559-568.

Tóth G, Gáspari Z and Jurka J (2000) Microsatellites in different eukaryotic genomes: survey and analysis. Genome Research 10: $967-981$.

Varshney RK, Graner A and Sorrells ME (2005) Genetic microsatellite markers in plants: features and applications Trends in Biotechnology 23: 48-55.

Vieira ESN, Schuster I, Silva RB and Oliveira MAR (2009) Variabilidade genética em cultivares de soja determinada com marcadores microssatélites em gel de agarose. Pesquisa Agropecuária Brasileira 44: 1460-1466.

Zane L, Bargelloni L and Patarnello T (2002) Strategies for microsatellite isolation: a review. Molecular Ecology 11: 116.

Yu K, Park J, Poysa V and Gepts P (2000) Integration of Simple Sequence Repeats (SSR) markers into a molecular linkage map of common bean (Phaseolus vulgaris). Journal Hereditas 91: $429-434$.

Yuste-Lisbona FJ, Capel C, Sarria E, Torreblanca R, GómezGuillamón ML, Capel J, Lozano R and López-Sesé AI (2011) Genetic linkage map of melon (Cucumis melo L.) and localization of a major QTL for powdery mildew resistance. Molecular Breeding 27: 181-192. 